\title{
Ditos de João Paulo II nas semanas de oração pela unidade dos cristãos - I
}

\author{
Orientadora: Prof ${ }^{a}$. Maria Teresa de Freitas Cardoso \\ Pesquisador: Luis Felipe Lañón Angamarca \\ Fonte: Departamento de Teologia

\section{Introdução}

Foi feito um estudo das características do ecumenismo espiritual e geral: sua noção, seus objetivos, fundamentos e orientações práticas para os católicos participarem do movimento ecumênico. Nosso estudo percorreu as audiências de João Paulo II proferidas nas Semanas de Oração pela Unidade dos Cristãos, que acontecem no mês de Janeiro. Foram selecionadas para o estudo as audiências dos anos de 1979 até 1984.

\section{Objetivos}

O estudo tinha em vista: descortinar pontos do pensamento ecumênico de João Paulo II enfatizados nas Semanas de Oração pela Unidade dos Cristãos; descobrir aspectos teológicos e práticos que ajudem a esclarecer, incentivar e orientar os cristãos católicos e outros que queiram ponderar os mesmos pontos para prosseguirem no ecumenismo e no aprofundamento da sua reflexão teológico-pastoral, para a busca de mais unidade dos cristãos e das pessoas em geral. 